\section{Pattern of Exotherm and Electrolyte Leakage Measured at High Frequency of Satsuma Mandarin Exposed to Subfreezing Temperatures}

\author{
R.C. Ebel, ${ }^{1}$ P.A. Carter, ${ }^{2}$ W.A. Dozier, ${ }^{3}$ D.A. Findley, ${ }^{4}$ M.L. Nesbitt, ${ }^{5}$ \\ B.R. Hockema, ${ }^{5}$ and J.L. Sibley ${ }^{6}$ \\ Department of Horticulture, Auburn University, Auburn, AL 36849
}

Additional index words. Citrus unshiu, Poncirus trifoliata, dehydration, cold hardiness, acclimation, freeze, differential thermal analysis

\begin{abstract}
The current study was conducted to relate ice formation to the pattern and rate of leaf and stem injury of Satsuma mandarins on trifoliate orange rootstock. Potted trees were unacclimated, moderately acclimated or fully acclimated by exposing trees to $32 / 21^{\circ} \mathrm{C}$, $15 / 7^{\circ} \mathrm{C}$ or $10 / 4^{\circ} \mathrm{C}$, respectively. Freezing treatments consisted of decreasing air temperature at $2{ }^{\circ} \mathrm{C} \cdot \mathrm{h}^{-1}$ until ice formed as evidenced by exotherms determined using differential thermal analysis of stems. Air temperature was then decreased, held constant, or increased and held constant to simulate severe, moderate and mild freeze conditions, respectively. All treatment exhibited exotherms at -2 to $-4{ }^{\circ} \mathrm{C}$, which were smaller with milder freezing treatments. Only the fully acclimated trees exhibited multiple exotherms. Leaf watersoaking, an indication of ice formation, occurred concurrently with stem exotherms except for fully acclimated trees where there was up to a 30-min delay and which corresponded with the second exotherm. Electrolyte leakage of leaves began to increase near the peak of the stem exotherm, but increased more slowly with milder freezing temperature treatments. In some treatments, electrolyte leakage reached a plateau near $50 \%$ but leaves survived. Leaves died when whole-leaf electrolyte leakage exceeded $50 \%$. These data are discussed within the framework of a proposed mechanism of injury of Satsuma mandarin leaves by subfreezing temperatures, especially multiple exotherms of fully acclimated trees, and the plateau of electrolyte leakage of leaves at the critical level for survival.
\end{abstract}

Commercial citrus crops are cold tenderevergreens (Webber et al., 1967) injured by temperatures between -2.2 to $-13{ }^{\circ} \mathrm{C}$ (Spiegal-Roy and Goldschmidt, 1996; Yelenosky, 1985; Yelenosky et al., 1981). In many parts of the world such as the southeastern U.S., citrus are grown in areas that are highly vulnerable to freezes that cause injury or tree death and significant economic losses (Attaway, 1997). Therehas been substantial research conducted to study the mechanism of injury (Spiegal-Roy and Goldschmidt, 1996; Yelenosky, 1985; 1996), however the mechanism is still not fully understood.

Citrus are injured by subfreezing temperatures only after ice forms within the tree (Spiegal-Roy and Goldschmidt, 1996; Yelenosky, 1985 , 1996), which usually occurs between -2.2 to $-6.7^{\circ} \mathrm{C}$ (Young, 1966). Ice can be initated anywhere in the canopy, and propagates

Received for publication 16 June 2003. Accepted 20 Mar. 2004. This project was funded in part by USDA Special Research Grants OEP \#2001-03124 and OEP\#2002-06162 and the Alabama Agricultural Experiment Station. We thank Charles Meadows and Research Instrumentation in the College of Agriculture for construction of the computer-controlled freezing chamber.

${ }^{1}$ Associate professor. Corresponding author; e-mail rcebel@acesag.auburn.edu.

${ }^{2}$ Graduate research assistant

${ }^{3}$ Professor

${ }^{4}$ Assistant professor.

${ }^{5}$ Research associate.

${ }^{6}$ Alumni associate professor. lethal when temperature drops below a critical minimum (Anderson, 1983; Young and Mann, 1974). Under some conditions, ice may penetrate into the symplast (Young and Mann, 1974) and propagate intercellularly (Rogers, 2000).

Studies that have related ice formation to injury did not use modern technology that allows data collection at high frequency. With the advent of computers, air temperature $\left(\mathrm{T}_{\text {air }}\right)$ in freeze chambers can be accurately controlled to within $\pm 0.2^{\circ} \mathrm{C}$ (Nesbitt et al., 2002), and the latent heat of fusion from ice formation can be measured at high frequency using differential thermal analysis (DTA). Such data may increase understanding of the specific mechanism by which intraplant ice causes injury. This study was conducted to measure electrolyte leakage (EL) of leaves as an indicator of injury and ice formation as measured by DTA at frequent intervals. Results are explained within the framework of our current theory of the mechanism of freeze injury of Satsuma mandarins.

\section{Materials and Methods}

Tree material and culture. Satsuma mandarin [Citrus unshiu (Marc.) 'Owari'] budded on trifoliate orange seedlings [Poncirus trifoliata (L.) Raf. 'Rubidoux'] with a single, staked shoot and that were 31 to $85 \mathrm{~cm}$ high were used in this experiment. Trees were grown in 3.7-L pots in a 1 pine bark : 1 sand substrate amended with $4.45 \mathrm{~kg} \cdot \mathrm{m}^{-3}$ of dolomitic lime, $8.9 \mathrm{~kg} \cdot \mathrm{m}^{-3}$ of N-P-K (18-6-12, Polyon 12 to 14 month slow-release fertilizer, Pursell Technologies, Inc, Sylacauga, Ala.) and $0.89 \mathrm{~kg} \cdot \mathrm{m}^{-3}$ of micronutrients (Micromax, The Scotts Co., Marysville, Ohio). Trees were grown outdoors in ambient conditions at Auburn, Ala., until acclimation treatments were initiated. Trees were irrigated daily with overtree sprinkler irrigation and fertilized weekly with Hoagland's solution (Hoagland and Arnon, 1938).

Acclimation treatments. Acclimation treatments were conducted in an environmental growth chamber (model E15; Conviron, Winnepeg, Canada) with fluorescent lighting (320 $\mu \mathrm{mol} \cdot \mathrm{m}^{-2} \cdot \mathrm{s}^{-1}$ at midtree height) and ambient relative humidity. The trees were irrigated daily and not fertilized during acclimation. There were three acclimation treatments. Trees were unacclimated, moderately acclimated or fully acclimated to cold temperatures. Acclimation treatments were chosen based on the relationship between temperature, growth and acclimation. Citrus growth ceases below $12{ }^{\circ} \mathrm{C}$, cold-acclimate below $10^{\circ} \mathrm{C}$ and are fully cold-hardened when exposed to $10{ }^{\circ} \mathrm{C}$ or less for 3 weeks (Bain, 1949; Cooper et al., 1954; Yelenosky et al., 1984; Yelenosky, 1985; Young, 1961; Young and Peynado, 1962, 1965).

Trees in the unacclimated treatment were held at $\mathrm{T}_{\text {air }}$ of $32 / 21^{\circ} \mathrm{C}$ and $12 / 12 \mathrm{~h}$ of light/dark photoperiod for 3 weeks, after which they were actively growing. Trees in the moderately acclimated treatment were exposed to $26 / 16{ }^{\circ} \mathrm{C}$ for $7 \mathrm{~d}, 20 / 11^{\circ} \mathrm{C}$ for $7 \mathrm{~d}$, and $15 / 7{ }^{\circ} \mathrm{C}$ for $11 \mathrm{~d}$, after which the trees had ceased growing. For each decrease in temperature, photoperiod was decreased by $30 \mathrm{~min}$ to $10.5 / 13.5 \mathrm{~h}$ of light/dark by the end of the moderate acclimation treatment. 
The decreases in photoperiod were conducted to approximate natural decreases in daylength for the Gulf Coast region of the U.S. where Satsuma mandarins are grown commercially. Trees in the fully acclimated treatment were exposed to temperatures that promoted maximum cold hardiness, $\mathrm{T}_{\text {air }}$ of $15 / 7^{\circ} \mathrm{C}$ for 3 weeks followed by $10 / 4{ }^{\circ} \mathrm{C}$ for 4 weeks (Yelenosky et al., 1984). Photoperiod was decreased similarly as for the moderately acclimated trees but decreased further for the fully acclimated trees and was 10/14 h the last 4 weeks of the acclimation treatment.

Freezing treatments. Freezing treatments were conducted after each acclimation treatment using a computer-controlled chest freezer (model FFF25C4AWD; Electrolux Home Products, Inc., Cleveland, Ohio) modified as described previously (Nesbitt et al., 2002). The freezer was further modified by fitting a Plexi-glass lid with a small access door below the freezer lid, which reduced the change in $\mathrm{T}_{\text {air }}$ within the freezer headspace as leaves were removed for sampling. Tree pots were fitted into styrofoam wells and potting media surfaces were covered with two layers of 1.6-cm-thick styrofoam insulation (R3, Dow, Midland, Mich.) and a layer of $6 \mathrm{~mm}$ insulating bubble wrap (R9.8, Reflectix, Inc., Markleville, Ind.) to prevent potting media from freezing (Nesbitt et al., 2002). The freezer was programmed to drop $\mathrm{T}_{\text {air }}$ linearly at $2{ }^{\circ} \mathrm{C} \cdot \mathrm{h}^{-1}$ to $4{ }^{\circ} \mathrm{C}$ and held at that temperature for 1 hour. The freezer was then programmed to decrease or increase $T_{\text {air }}$ at $2{ }^{\circ} \mathrm{C} \cdot \mathrm{h}^{-1}$ or hold it constant, depending on the specific freezing treatment. The first freezing treatment was conducted to determine the temperature of exotherms, and consisted of a continuous drop to $-12{ }^{\circ} \mathrm{C}$ (Fig. 1 ; U1, M1, and $\mathrm{F} 1)$. The second freezing treatment consisted of a decrease in temperature to about 0.5 to $1{ }^{\circ} \mathrm{C}$ below the peak of the exotherm of the $-12{ }^{\circ} \mathrm{C}$ freezing treatment, and then held constant at that temperature. $\mathrm{T}_{\text {air }}$ in the third freezing treatment was dropped to the same temperature as the second freezing treatment, but then increased to and held constant at -2.0 or $-3.5^{\circ} \mathrm{C}$.

Datacollected. Ice formation was determined in tree stems for all freezing treatments by differential thermal analysis (Ketchie and Kammereck, 1987). Two 32-gauge copper-constantan thermocouples were attached at about 10 and $35 \mathrm{~cm}$ above the graft union of each tree and wrapped in parafilm. Thermocouple leads were connected to a computer and temperature collected and stored every 2 s (PC64 datalogging software; Lawson Labs, Kalispell, Mont.).

Electrolyte leakage (EL) of leaves was determined before freezing and every $30 \mathrm{~min}$ during each freezing run. A single mature leaf was randomly selected from each tree at each sampling time and removed. EL was determined according to Nesbitt et al. (2002). EL due to freeze injury was expressed as a percent using the equation proposed by Flint et al. (1967) where $\mathrm{EL}=\left[\left(\mathrm{EL}_{\text {frozen }}-\mathrm{EL}_{\text {boiled }}\right) /\left(\mathrm{EL}_{\text {prefrozen }}\right.\right.$ $\left.\left.-\mathrm{EL}_{\text {boiled }}\right)\right] \times 100$.

After each freezing run, trees were removed from the freezer and placed in a greenhouse under ambient conditions and cultured to promote growth. After 2 to 4 weeks, stem dieback was determined by measuring the length of dead tissue from the tip back of the main central leader and expressed on a percent dieback basis by measuring the length of the entire stem from the tip to the graft union.

Statistical analysis. Six trees were used as replications for each freezing treatment, except the first freezing run for fully acclimated trees where four trees were used.

Stem exotherms for each thermocouple were smoothed by taking the average of readings every $800 \mathrm{~s}$ before and after each data point. Smoothing reduced fluctuations caused by the on/off cycling of the freezer heaters that resulted in a $\pm 0.2{ }^{\circ} \mathrm{C}$ variation about the mean $\mathrm{T}_{\text {air }}$ (Nesbitt et al., 2002), and during opening of the lid to remove samples, which increased $\mathrm{T}_{\text {air }}$ an average of $2{ }^{\circ} \mathrm{C}$.

Differences in dieback among freezing treatments within each acclimation treatment were determined using the GLM procedure of SAS. Means were separated using Duncan's multiple range test $(P \leq 0.05)$.

\section{Results and Discussion}

Ice formation. A major exotherm occurred for all treatments between 1 to $3 \mathrm{~h}$ after the start of each freezing treatment (Fig. 1, U2,
M2, and F2). Exotherms occurred when $\mathrm{T}_{\text {air }}$ was between -2.0 to $-4.0^{\circ} \mathrm{C}$, which lies in the range that typically causes ice to form in citrus (Yelenosky, 1985). The highest temperature differentials of exotherms varied from 0.3 to 0.7 ${ }^{\circ} \mathrm{C}$, and exhibited a rapid increase followed by a gradual decline. In general, exotherms were smaller with milder freezing treatments within each acclimation treatment, indicating less water freezing. In most treatments, stem differential temperature eventually dropped to baseline (stem differential temperature of $0{ }^{\circ} \mathrm{C}$.

Trees of most treatments exhibited only one exotherm, however, there appeared to be up to three exotherms for fully acclimated trees, with the peak of the second exotherm occurring at $4 \mathrm{~h}$ and the third at or after $6 \mathrm{~h}$ when data collection was terminated(Fig. 1, C2). Multiple exotherms have been reported for deciduous crops, which have been related to differential cold hardiness among tissues in deciduous species (Ketchie and Kammereck, 1987; McLeester et al., 1969; Quamme et al., 1972; Rajashekar et al., 1982). Only one report indicated multiple exotherms occurred for citrus leaves (Jackson and Gerber, 1963). Citrus stem tissues vary in cold hardiness (Nesbittet al., 2002), but no reports have related tissues to specific exotherms.
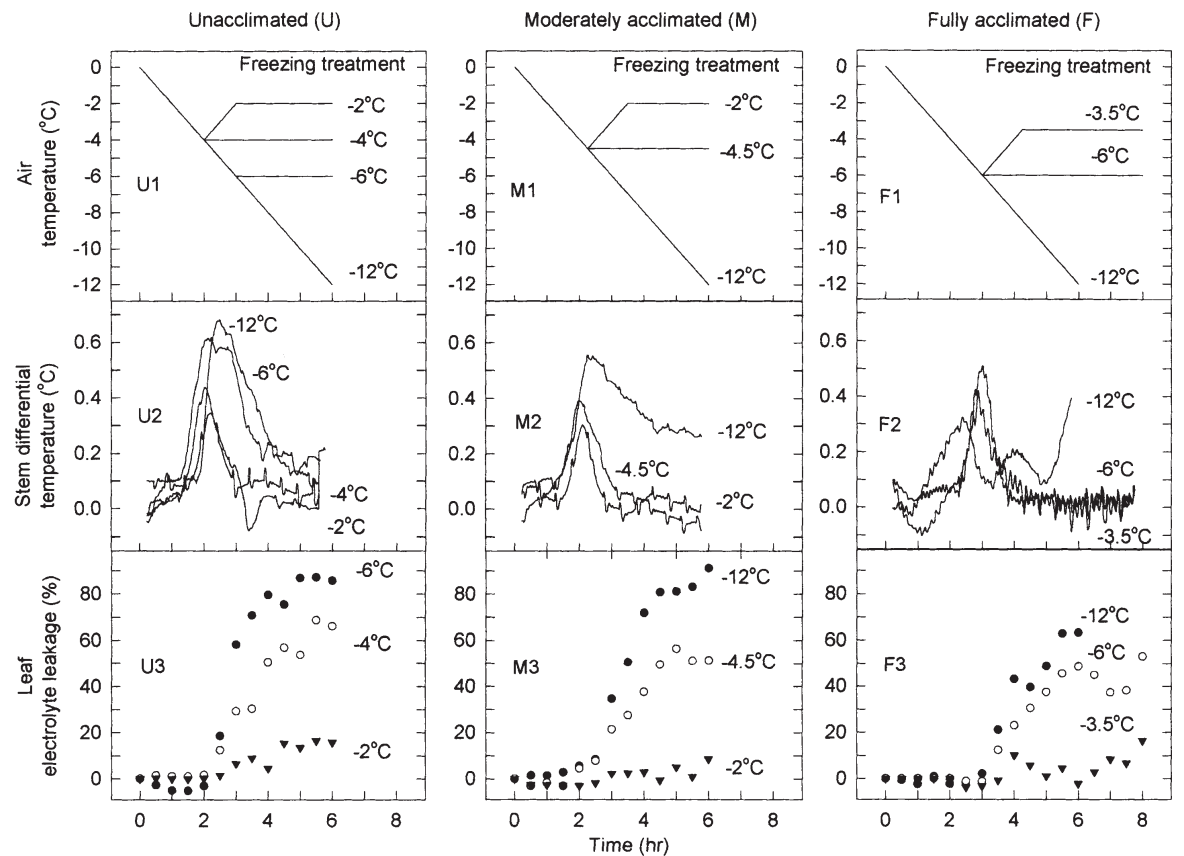

Fig. 1. Air temperatures for each freezing treatment (U1, M1 and F1) and the effect on stem ice formation measured by differential thermal analysis (U2, M2, and F2), and leaf electrolyte leakage (U3, M3, and $\mathrm{F} 3$ ). Above each column of graphs is the acclimation treatment, which was $32 / 21^{\circ} \mathrm{C}, 15 / 7^{\circ} \mathrm{C}$ or $10 / 4^{\circ} \mathrm{C}$ for the unacclimated $(\mathrm{U})$, moderately acclimated $(\mathrm{M})$ or fully acclimated $(\mathrm{F})$ trees, respectively. Each differential thermal analysis curve and electrolyte leakage data point is a mean from six trees.

Table 1. Percent dieback of Satsuma mandarin shoots at different cold hardiness levels induced by three acclimation treatments and exposed to various freezing temperatures.

\begin{tabular}{|c|c|c|c|c|c|}
\hline \multicolumn{6}{|c|}{ Day/night acclimation temp } \\
\hline \multicolumn{2}{|c|}{$32 / 21^{\circ} \mathrm{C}$} & \multicolumn{2}{|c|}{$15 / 7{ }^{\circ} \mathrm{C}$} & \multicolumn{2}{|c|}{$10 / 4{ }^{\circ} \mathrm{C}$} \\
\hline $\begin{array}{l}\text { Freezing } \\
\text { treatment } \\
\left({ }^{\circ} \mathrm{C}\right)\end{array}$ & $\begin{array}{c}\text { Shoot } \\
\text { dieback } \\
(\%)\end{array}$ & $\begin{array}{l}\text { Freezing } \\
\text { treatment } \\
\left({ }^{\circ} \mathrm{C}\right)\end{array}$ & $\begin{array}{c}\text { Shoot } \\
\text { dieback } \\
(\%)\end{array}$ & $\begin{array}{c}\text { Freezing } \\
\text { treatment } \\
\left({ }^{\circ} \mathrm{C}\right)\end{array}$ & $\begin{array}{c}\text { Shoot } \\
\text { dieback } \\
(\%)\end{array}$ \\
\hline-12.0 & $100 \mathrm{a}^{\mathrm{z}}$ & -12.0 & $100 \mathrm{a}$ & -12.0 & $100 \mathrm{a}$ \\
\hline-6.0 & $100 \mathrm{a}$ & -4.5 & $5 \mathrm{~b}$ & -6.0 & $0 \mathrm{~b}$ \\
\hline-4.0 & $38 \mathrm{~b}$ & -2.0 & $0 \mathrm{~b}$ & -3.5 & $0 \mathrm{~b}$ \\
\hline-2.0 & $0 \mathrm{c}$ & --- & --- & --- & --- \\
\hline
\end{tabular}

${ }^{2}$ Letters within columns indicate significant differences using Duncan's multiple range test $(P \leq 0.05)$. 
When citrus trees freeze, ice is typically initiated at a single or few locations and spreads rapidly throughout the entire canopy (Yelenosky, 1991). The time exotherms traveled between the two thermocouples on a tree was $<1 \mathrm{~min}$. Water soaking, an indicator of ice formation in leaves (Young and Peynado, 1967), was observed to occur within $30 \mathrm{~min}$ of each exotherm. Based on these data, we conclude that ice began to form in leaves within $30 \mathrm{~min}$ after the exotherm peak of the stems.

Leaf electrolye leakage. For trees exposed to the $-12{ }^{\circ} \mathrm{C}$ freezing treatment, EL began to increase near the peak of the single exotherm for unacclimated (Fig. 1, U3) and moderately acclimated (Fig. 1, M3) trees, whereas EL of the fully acclimated trees (Fig. 1, F3) increased with onset of the second exotherm. EL increased with time for all treatments, but increased more slowly for milder freezing treatments. For some treatments, the stem differential temperature dropped back to $0^{\circ} \mathrm{C}$, yet EL still increased. For example, unacclimated trees exposed to $-4{ }^{\circ} \mathrm{C}$ had stem differential temperature drop to $0{ }^{\circ} \mathrm{C}$ by $4 \mathrm{~h}$ (Fig. 1, U2), but EL continued to increase from $50 \%$ to $70 \%$ from 4 to $6 \mathrm{~h}$ (Fig. 1, U3). It is likely that additional water froze, but the heat released dissipated such that what reached the thermocouple was below its detection limit. Moderately acclimated trees exposed to $-4.5^{\circ} \mathrm{C}$ (Fig. 1, M2) and fully acclimated trees exposed to $-6{ }^{\circ} \mathrm{C}$ (Fig. 1, C2) had EL level off near $50 \%$, which may indicate differential response of various tissues. Since these leaves survived, the tissue critical to survival was not killed.

Leaf watersoaking was observed to develop simultaneously with the increase in EL for all treatments. Watersoaking developed near the petiole first along with small patches scattered throughout the lamina that grew and coalesced. The entire leaves of unacclimated trees were completely watersoaked for all freezing treatments. Leaves of fully acclimated trees were not completely watersoaked. The amount of watersoaking tended to be less with increased acclimation and milder freezing treatments.

Stem dieback and bark cracking. The entire stem and all leaves were killed when $\mathrm{T}_{\text {air }}$ was decreased to $-12{ }^{\circ} \mathrm{C}$ for all acclimation treatments, and $-6^{\circ} \mathrm{C}$ for unacclimated trees (Table 1). Dieback for the $-4.0^{\circ} \mathrm{C}$ freezing treatment of unacclimated trees was intermediate to the -2.0 and $-4.0^{\circ} \mathrm{C}$ freezing treatments. Wholeleaf survival related closely to stem survival. In all treatments where there was stem dieback and leaf necrosis, whole-leaf EL increased over $50 \%$. Bark cracking was evident only on unacclimated trees and was observed to be less with milder freezing treatments.

The results of this study fit within the framework of our current theory of citrus tree injury by subfreezing temperatures. Ice spreads rapidly throughout the entire canopy. Bulk water froze in the stem followed by an increase in EL, which was very slow in some freezing treatments, supporting the contention that water freezes in the apoplast. If water within the leaf symplast froze during this exotherm, the symplast would have been killed instantly causing EL to rise above $50 \%$, the level that is lethal (Levitt, 1956), also during the exotherm. Although tissue water content was not measured, unacclimated trees had larger exotherms, more watersoaking, and more bark cracking indicating higher water content than acclimated trees. For unnacclimated trees, it is clear that at least with bark cracking, the expansion of ice caused direct injury to the trees, although this does not preclude symplastic dehydration. For fully acclimated trees, the lack of complete watersoaking of leaves indicates that there was still sufficient space in the apoplast for ice to form, and thus direct penetration of cells probably did not occur. The presence of multiple exotherms for fully acclimated trees indicates a differential response of different tissues in the stems, but the tissues that correspond to each exotherm needs to be determined. The plateau in EL near $50 \%$ for the $-4.5^{\circ} \mathrm{C}$ freezing treatment of the moderately acclimated trees and the $-6^{\circ} \mathrm{C}$ of the fully acclimated trees probably indicates differential tissue response within leaves, and that the tissues critical to survival were notkilled. Additional research needs to be conducted to determine what leaf tissue is critical to survival. This study demonstrated that under some acclimation treatments and subfreezing temperatures, Satsuma mandarins exhibit multiple exotherms in stems and a plateau in leaf EL, which likely indicates differential response among tissues of these two organs.

\section{Literature Cited}

Anderson, J.A., L.V.Gusta, D.W. Buchanan, and M.J. Burke. 1983. Freezing of water in citrus leaves. J. Amer. Soc. Hort. Sci. 198:397-400.

Attaway, J.A. 1997. A history of Florida citrus freezes. Florida Science Source, Inc. Lake Alfred, FL. ISBN 0-944961-03-7.

Bain,F.M. 1949. Citrus and climate. Calif. Citrograph 34:382-449.

Cooper, W.C., B.S. Gorton, and S. Tayloe. 1954 Freezing tests with small trees and detached leaves of grapefruit. Proc. Amer. Soc. Hort. Sci. 63:167-172.

Flint, H.L., B.R. Boyce, and D.J. Beattie. 1967. Index of injury: A useful expression of freezing injury to plant tissues as determined by electrolyte leakage. Can. J. Plant Sci. 47:229-230.

Hoagland, D.R. and D.I. Arnon. 1938. The water-culture method for growing plants without soil. Univ. Calif. College Agr., Agr. Expt. Sta.Circ. 347.

Jackson, L.K. and J.F. Gerber. 1963. Cold tolerance and freezing point of citrus seedlings. Proc. Fla. State Hort. Soc. 76:70-74.

Johnson-Flanagan, A.M. and J. Singh. 1986. Membrane deletion during plasmolysis in hardened and non-hardened plant cells. Plant Cell Env. 9:299-305

Ketchie, D.O. and R. Kammereck. 1987. Seasonal variation of cold resistance in Malus woody tissue as determined by differential thermal analysis and viability tests. Can. J. Bot. 65:2640-2645.

Levitt, J. 1956. The hardiness of plants. Academic Press, Inc., New York. p. 278.

Lucas, J.W. 1954. Subcooling and ice nucleation in lemons. Plant Physiol. 29:246-251.

McLeester, R.C., C.J. Weiser, and T.C. Hall. 1969. Multiple freezing points as a test for viability of plant stems in the determination of frost hardiness. Plant Physiol. 44:37-44.

Meryman, H.T. 1956. Mechanics of freezing in living cells and tissues. Science 124:515-521.

Meryman, H.T. 1966. Review of biological freezing, p. 2-114. In: H.T. Meryman (ed.). Cryobiology. Academic Press, New York.
Nesbitt, M. L., R.C. Ebel, D. Findley, B. Wilkins, F. Woods, D. Himelrick. 2002. Assays to assess freeze injury of Satsuma mandarin. HortScience 37:871-877.

Quamme, H. C. Stushnoff, and C.J. Weiser. 1972. The relationship of exotherms to cold injury in apple stem tissues. J. Amer. Soc. Hort. Sci. 97:608-613.

Rajashekar, C., H.M. Pellet, and M.J. Burke. 1982. Deep supercooling in roses HortScience 17:609-611.

Ristic, Z. and E.N. Ashworth. 1994. Response of xylem ray parenchyma cells of red osier dogwood (Cornus sericea L.) to freezing stress. Plant Physiol. 104:737-746.

Rogers, S. 2000. Supercooling and ice nucleation in citrus leaves. Proc. Intl. Soc. Citricult. IX Congr., p. 396-400.

Singh, J. 1979. Ultrastructural alterations in cells of hardened and non-hardened winter rye during hyperosmotic and extracellular freezing stresses. Protoplasma 98:329-341.

Speigel-Roy,P., and E.E. Goldschmidt. 1996. Biology of citrus. Cambridge Univ. Press, New York.

Webber, H.J., W. Reuther, and H.W. Lawton. 1967. History and development of the citrus industry, p. 1-39. In: W. Reuther, H.J. Webber, and L.D. Batchelor (eds.). The citrus industry. vol. 1. Div. Agr. Sci., Univ. Calif., Berkeley.

Yelenosky, G. 1975. Cold hardening in citrus stems. Plant Physiol. 56:40-543.

Yelenosky, G. 1978. Coldhardening 'Valencia' orange trees to tolerate $-6.7^{\circ} \mathrm{C}$ without injury. J. Amer. Soc. Hort. Sci. 103:449-452.

Yelenosky, G. 1982. Indicators of citrus cold-hardening in the field. Proc. Fla. State Hort. Sci. 95:7-10.

Yelenosky, G. 1985. Cold hardiness in citrus. Hort. Rev. 7:201-238.

Yelenosky, G. 1991. Apparent nucleation and freezing in various parts of young citrus trees during controlled freezes. HortScience 26:576-579.

Yelenosky, G. 1996. An overview of Florida citrus freeze survival. Proc. Fla. State Hort. Soc. 109:118-123

Yelenosky, G., C.J. Hearn, and D.J. Hutchison. 1984. Nonhardening temperatures-Major factor in freeze damage to citrus trees in December 1983. Proc. Fla. State Hort. Soc. 97:33-36

Yelenosky, G., R. Young, C.J. Hearn, H.C. Barrett, and D.J.Hutchison. 1981. Cold hardiness of citrus trees during the 1981 freeze in Florida. Proc. Fla. State Hort. Soc. 94:46-51.

Young, R.H. 1961. Influence of day length, light intensity, and temperature on growth, dormancy, and cold-hardiness of Red Blush grapefruit trees. Proc. Amer. Soc. Hort. Sci. 78:174-180.

Young, R. 1966. Freezing points and lethal temperatures of citrus leaves. Proc. Amer. Soc. Hort Sci. 88:272-279.

Young, R.H. 1970. Induction of dormancy and cold hardiness in citrus. HortScience 5:411-413.

Young, R.H. and M. Mann. 1974. Freeze disruption of sour orange leaf cells. J. Amer. Soc. Hort. Sci. 99:403-407.

Young, R.H. and A. Peynado. 1962. Growth and cold-hardiness of citrus and related species when exposed to different night temperatures. Proc. Amer. Soc. Hort. Sci. 81:238-243.

Young, R.H. and A. Peynado. 1965. Changes in cold hardiness and ceratin physiological factors of Redblush grapefruit seedlings as affected by exposure to artificial hardening temperatures. Proc. Amer. Soc. Hort. Sci. 86:244-252.

Young, R. and A. Peynado. 1967. Freezing and water-soaking in citrus leaves. Amer. Soc. Hort. Sci. 91:157-162. 